\title{
Primary hypothyroidism with paradoxically elevated plasma thyroxine due to thyroxine-binding antibody
}

\author{
R.V. Hague, S.P. Higgins and W.J. May \\ Department of Medicine, District General Hospital, Gawber Road, Barnsley, South Yorkshire S75 2EP, UK.
}

\begin{abstract}
Summary: Investigation of an elderly patient with clinical hypothyroidism revealed a low serum triiodothyronine $\left(T_{3}\right)$ but markedly raised levels of total thyroxine $\left(\mathrm{TT}_{4}\right)$ and free thyroxine $\left(\mathrm{fT}_{4}\right)$ when measured by radio-immunoassay (RIA). Primary hypothyroidism was suggested by an elevated basal thyroid stimulating hormone (TSH) and confirmed by a low $\mathrm{fT}_{4}$ when measured by a commercial microencapsulated antibody method. The paradoxically elevated levels of $\mathrm{fT}_{4}$ and $\mathrm{TT}_{4}$ were due to the presence of an antibody which specifically bound $T_{4}$ and grossly interfered with the RIA thus complicating the diagnosis and later the assessment of replacement therapy. The sensitive immunoradiometric TSH assay proved of value in resolving these problems.
\end{abstract}

\section{Introduction}

Antibodies to thyroid hormones have occasionally been demonstrated in association with various thyroid disorders (Robbins et al., 1956; Premachandra \& Blumenthal, 1967; Ochi et al., 1972), but only recently have cases been reported in which their presence was thought to be of clinical significance (Hermann et al., 1977; Karlsson et al., 1977; Beckett et al., 1983).

The diagnosis of primary hypothyroidism is usually confirmed by finding a low plasma concentration of total thyroxine $\left(\mathrm{TT}_{4}\right)$ in association with a raised plasma thyroid stimulating hormone (TSH) level. In this paper we present a patient with primary hypothyroidism in whom antibodies to thyroxine interfered with radio-immunoassays resulting in elevated levels which not only complicated the diagnosis but also the subsequent management of the case.

\section{Case report}

In 1983 a 69 year old woman presented giving a 3 month history of tiredness, hoarseness, cold intolerance, confusion, weight gain and constipation. Her niece had previously been treated for hypothyroidism due to Hashimoto's thyroiditis.

Clinically the patient was confused and appeared myxoedematous in that her skin was cool, dry and

Correspondence: R.V. Hague, F.R.C.P.

Accepted: 27 February 1986 flaky and her hair was brittle. The thyroid gland was normal.

The electrocardiogram was of low voltage. Serum cholesterol was $12 \mathrm{mmol} / 1$ (normal $3.6-7.6 \mathrm{mmol} / \mathrm{l}$ ); thyroxine binding globulin $11 \mathrm{mg} / 1$ (normal $8.3-15.9 \mathrm{mg} / \mathrm{l})$; thyroglobulin antibody titre $1: 2,480$ and thyroid microsomal antibody titre $1: 6,400$. Intrinsic factor antibodies were negative. ${ }^{99} \mathrm{~m}$ Tc pertechnetate thyroid scan was normal. The erythrocyte sedimentation rate was $8 \mathrm{~mm} / \mathrm{h}$.

Total thyroid hormone levels performed by radioimmunoassay (Amerlex: Amersham International $\mathrm{UK}$ ) were total thyroxine $\left(\mathrm{TT}_{4}\right) 670 \mathrm{nmol} / 1$ (normal $60-170 \mathrm{nmol} / \mathrm{l})$ and total triiodothyronine $\left(\mathrm{TT}_{3}\right)$ $0.66 \mathrm{nmol} / 1$ (normal $0.7-2.86 \mathrm{nmol} / \mathrm{l}$ ); free thyroxine (fT $\mathrm{f}_{4}$ ) measured by an analogue-based RIA (Amerlex M; Amersham International UK) was markedly elevated at $290 \mathrm{pmol} / 1(9-23 \mathrm{pmol} / \mathrm{l})$ but when measured by a microencapsulated antibody technique (Liquisol, CIS UK) $\mathrm{fT}_{4}$ was clearly reduced at $3.4 \mathrm{pmol} / 1$ (normal $10-30 \mathrm{pmol} / \mathrm{l}$ ). Thyroid stimulating hormone (Corning Medical, Halstead, Essex) was elevated at $36 \mathrm{mU} / 1$ (normal $<7 \mathrm{mU} / 1)$.

Non-specific binding by the patient's serum of the $\mathrm{T}_{4}$ tracer used for RIA was greatly elevated at $55 \%$ (euthyroid control 3\%). Electrophoresis of the patient's serum after addition of the $\mathrm{T}_{4}$ tracer demonstrated a marked increase in tracer concentration in the gamma-globulin region. Plasma IgG was $22.6 \mathrm{~g} / 1$ (normal 5-16 g/l).

Regular supervised treatment with thyroxine $50 \mu \mathrm{g} /$ 
day was commenced and within one month the TSH had fallen to $2 \mathrm{mU} / 1$ and there was a normal response to thyrotrophin releasing hormone $200 \mu \mathrm{g}$ i.v. (TSH levels 2,7 and $8 \mathrm{mU} / 1$ at 0,20 and 60 minutes, respectively). At this time, TSH levels measured by a sensitive immunoradiometric assay (Boots Celltech $\mathrm{UK})$ were normal at $1.6 \mathrm{mU} / 1(0.27-5.5 \mathrm{mU} / \mathrm{l})$. $\mathrm{TT}_{4}$ had fallen to $198 \mathrm{nmol} / 1$ when measured by RIA but equilibrium dialysis (Gow et al., 1985) revealed an $\mathrm{fT}_{4}$ of $18 \mathrm{pmol} / 1$ (normal $8.5-17.0 \mathrm{pmol} / \mathrm{l}$ ). The latter technique was used to measure the post-treatment $\mathrm{fT}_{4}$ because the Liquisol method was no longer available to us. Within 3 months all the clinical features had resolved apart from the confusion which was unchanged.

\section{Discussion}

Antibodies to thyroid hormones were first described in 1956 (Robbins et al., 1956) and although they have been demonstrated in the plasma of many patients with various thyroid disorders (Premachandra \& Blumenthal, 1967; Ochi et al., 1972) their significance has been uncertain. Their discovery has usually been thought to be accessory to the clinical findings but more recently cases have been described in which hypothyroidism has been associated with antibodies to $\mathrm{T}_{4}$ (Hermann et al., 1977) to $\mathrm{T}_{3}$ (Karlsson et al 1977) and to $T_{3}, T_{4}$ and reverse $T_{3}$ (Beckett et al., 1983).

This case illustrates the difficulty in interpreting thyroid function tests in patients with high levels of abnormal thyroid hormone binding proteins. The presence of antibody rendered total thyroid hormone and analogue $\mathrm{fT}_{4}$ assays useless, thus hampering both the biochemical confirmation of the clinical diagnosis and the monitoring of replacement therapy. Although $\mathrm{TT}_{4}$ levels fell after adequate replacement therapy they remained elevated slightly above normal, presumably because free binding sites remained on the patient's antibody which combined with tracer added during

\section{References}

BECKETT, G.J., TODD, J.A., HUGHES, G.J. \& CAMPBELL, I.W. (1983). Primary hypothyroidism with grossly elevated plasma total thyroxine and triiodothyronine levels. Clinical Endocrinology, 19, 295.

CALDWELL, G., KELLETT, H.A., GOW, S.M., BECKETT, G.J., SWEETING, V.M., SETH, J. \& TOFT, A.D. (1985). A new strategy for thyroid function testing. Lancet, $\mathrm{i}, 1117$.

GOW, S.M., KELLETT, H.A. \& BECKETT, G.J. (1985). Accuracy and precision of five analog radioimmunoassays for free thyroxin compared. Clinical Chemistry, 3, 1888.

HERMANN, J., RUDORFF, K.H., KRONER, H. \& PREMACHANDRA, B.N. (1977). Antibody binding of thyroid hormone in juvenile goitrous hypothyroidism. Hormone and Metabolic Research, 9, 394.

KARLSSON, F.A., WIBELL, L. \& WIDE, L. (1977). Hypoth- the assay procedure. Since the total thyroxine level is calculated as being inversely proportional to the amount of tracer bound solely to the antibody attached to the solid phase (Amerlex) particles used in the assay, this would account for the apparent elevation in $\mathrm{TT}_{4}$.

Conventional TSH assays on random samples are not sufficiently sensitive in the low normal range to detect over-treatment, and this diminished the value of the normal TSH result obtained after one month of treatment. The picture was clarified by TRH testing and by the use of both a sensitive TSH assay and an $\mathrm{fT}_{4}$ measurement by equilibrium dialysis.

This case is of particular interest in that antibody directed against $T_{4}$ not only interfered with conventional thyroid function tests but may also have contributed to the production of clinical hypothyroidism in a patient whose thyroid reserve was limited by an auto-immune thyroiditis. When we consider the methods which were of most value in assessing this patient, measurements of $\mathrm{fT}_{4}$ by equilibrium dialysis and by the Liquisol method are not generally available for routine thyroid testing and the former is at present only a research technique. TRH testing is time consuming. The sensitive immunoradiometric TSH assay (Boots Celltech UK) has recently (Caldwell et al., 1985) been proposed as a means of rationalizing routine tests of thyroid function, although at the moment its availability is limited only to certain centres. Nevertheless, it may be that this technique alone could prove to be the best for establishing the diagnosis and monitoring replacement therapy in patients with thyroid hormone binding antibodies.

\section{Acknowledgements}

We would like to thank Dr G.J. Beckett for his helpful advice and criticism, and Mrs D. Grayson for typing the manuscript.

yroidism due to thyroid-hormone-binding antibodies. New England Journal of Medicine, 296, 1146.

OCHI, Y., SHIOMI, K., HACHIYA, T., YOSHIMURA, M. \& MIYAZAKI, T. (1972). Immunological analysis of abnormal binding of thyroid hormone in the gamma globulin. Journal of Clinical Endocrinology and Metabolism, 35, 743.

PREMACHANDRA, B.N. \& BLUMENTHAL, H.T. (1967). Abnormal binding of thyroid hormone in sera from patients with Hashimoto's disease. Journal of Clinical Endocrinology, 27, 931.

ROBBINS, J., RALL, J.E., RAWSON, R.W. (1956). An unusual instance of thyroxine binding by human serum gamma globulin. Journal of Clinical Endocrinology and Metabolism, 16, 573 . 